\title{
A Szepes vármegyére vonatkozó középkori oklevelek nyelvtörténeti feldolgozásának filológiai tanulságai
}

\author{
KENYHERCZ RÓBERT
}

\section{Bevezetés}

A középkori oklevelek helynévi szórványaival kapcsolatban ma már elmondható, hogy a rendelkezésre álló adatok mennyisége és minősége, valamint az adatok elemzésének technikai lehetőségei minden korábbi időszakhoz képest lényegesen egyszerübbé és hatékonyabbá teszik bizonyos nyelv- és névtörténeti kérdések feldolgozását. ${ }^{1}$ Míg korábban az okleveles helynévi anyag tömeges és szisztematikus vizsgálatba vonásának a várható eredményei többnyire még csak reménységgel töltötték el a kutatókat (vö. pl. BÁRCZI 1958: 144, NYIRKOS 1997: 256, HOFFMANN 1997: 95), azt gondolom, hogy ma már a várakozások és jóslatok a tekintetben beteljesülni látszanak, hogy az oklevelek nyelvi feldolgozásából elóállt korpuszok ${ }^{2}$ használata az utóbbi években-évtizedekben valódi, esetenként kifejezetten jelentősnek mondható eredményeket is hozott a tulajdonnevek, s ezzel együtt a magyar nyelv történetének a kutatásában. Azonban az oklevelek helynévi szórványai — mint általában a nyelvtörténeti adatok — a rendelkezésre álló adatbázisok minősége és mérete ellenére is csak erősen töredékes kép megmutatására alkalmasak. Így a rejtve maradt részeket, hiányokat — amelyek kapcsán már olykor az is kérdéses, hogy a kép, amit látunk, mennyire töredékes - elméleti és módszertani alapvetések mentén vagyunk kénytelenek kitölteni. Ezzel kapcsolatban úgy látom, hogy egy-egy oklevél, oklevélfajta vagy szórványtípus monografikus mélységü feldolgozása az utóbbi években olyan tapasztalatokat

${ }^{1}$ Az hangsúlyozni kell, hogy az oklevelek helynévi szórványainak a segítségével vizsgálható területek köre korlátozott, mert míg például hangtörténeti kérdésekben vagy a nyelvi érintkezések feltárásakor egészen kiváló források, (morfo)szintaktikai szempontból a jelentőségük szinte figyelmen kívül hagyható. Ezért amikor a továbbiakban a helynévi szórványok forrásértékéről beszélek, természetesen mindig az általuk közvetíteni képes nyelvi szintekre vonatkoztatva értem azt.

${ }^{2}$ Itt elsősorban a Korai magyar helynévszótár és a Helynévtörténeti adatok a korai ómagyar korból köteteit lehet megemlíteni, valamint az ezeken és Györffy György történeti földrajzának adatain alapuló digitális adatbázisokat (ezekhez lásd a Magyar Névarchívum honlapját, http://mna. unideb.hu). 
eredményezett (pl. HoFFMANN 2007, 2010, KovÁCs É. 2015, 2018, SZENTGYÖRGYI 2014, SZÖKE 2015, de lásd még BÁBA 2016, RÁCZ 2016, sőt a személynévi szórványok vizsgálatának a tapasztalatai is egyértelmúen idekapcsolhatók, pl. SLíz 2017, TóTH 2016, 2017), amelyek mind az egy-egy konkrét név eredetét célzó, mind a nagyobb anyagmennyiségen történő nyelv- és névtörténeti vizsgálatok szemléletét megváltoztatták. ${ }^{3}$

Az oklevelek helynévi szórványainak a kérdéseivel magam az elmúlt években Szepes vármegye középkori okleveleinek a nyelvészeti feldolgozása kapcsán kezdtem el mélyebben foglalkozni. Noha az elsődleges célom egy Szepes vármegyére vonatkozó névtár és történeti-etimológiai helynévszótár elkészítése volt, az adatok gyüjtése és értelmezése során az okleveles szórványok nyelv- és névtörténeti hasznosíthatóságának az ügyei is rendre előkerültek. A vármegye forrásanyagának a szempontjából számomra leginkább izgalmasnak tủnő problémákkal — úgymint a nyelvi presztízs és az okleveles normatörekvések összefüggéseinek a kérdése, valamint az oklevelek hangjelölési és átírási gyakorlata — korábban már több munkámban foglalkoztam (vö. 2013b, 2016, de lásd még 2014, 2018), s mostani írásommal is e kérdéskörhöz szeretnék kapcsolódni. E tanulmány írásának az idejére lényegében végére értem az említett történeti-etimológiai szótárhoz kapcsolódó szepesi okleveles források feldolgozásának, s az alábbiakban az adatgyüjtés tapasztalatai alapján azokat a kérdéseket szeretném érinteni, amelyek megfogalmazása és megválaszolása véleményem szerint nem csupán hasznos, de szükséges kontextusát is adhatja az oklevelek szórványaira irányuló nyelvtörténeti vizsgálatoknak.

\section{A kutatási háttér}

Azt hiszem, ma már nem különösebben szükséges hangsúlyozni, hogy az adatbőség és az adatminőség mennyire fontos két pillére a nyelv- és névtörténeti kutatásoknak. Szepes vármegyére vonatkozóan azonban modern, nyelvészeti vizsgálatokra is használható történeti földrajz nem áll rendelkezésre. CsÁNKInál szerepel ugyan Szepes vármegye, de adatainak a megbízhatósága - a mü egészére jellemző módon - nyelvészeti szempontból nagyon változó, a GYÖRFFYkötetek kiadása pedig nem jutott el eddig a megyéig. Megemlíthető még FEKETE NAGY ANTAL A Szepesség területi és társadalmi kialakulása címü monográfiája is (1934), azonban ennek a munkának nem a szisztematikus adatközlés volt a célja. A forráskiadásokkal kapcsolatban pedig az mondható el, hogy a területre vonatkozó oklevelek egy jó része a mai napig feldolgozatlan, vagy csupán

\footnotetext{
${ }^{3}$ Itt főként arra a szemléletbeli elmozdulásra gondolok, amely a hagyományos helynév-etimológia irányából a helynév-rekonstrukció módszertanának a kikristályosodása felé történt meg. Ehhez lásd pl. HOFFMANN 2007, HOFFMANN-RÁCZ-TóTH 2018: 459-470, de különösen TóTH 2019.
} 
régi, nyelvészeti szempontból sokszor használhatatlan szövegkiadásokban és regesztákban érhető el. ${ }^{4}$ Hamar kiderült tehát számomra, hogy a kutatás első lépéseként megkerülhetetlen, hogy az oklevelekből közvetlenül gyüjtsek adatokat. Amellett, hogy az adatgyüjtés így kezdetben meglehetösen lassan haladt, hiszen tanulnom kellett az oklevelek olvasását, a korábbi évtizedek kutatásaihoz képest hatalmas előnyöm volt, hogy a Magyar Nemzeti Levéltár, illetve részben a Monasterium elnevezésü nemzetközi projekt munkájának köszönhetően az okleveleket nem levéltárakban vagy nehezen kezelhető mikrofilmes felvételeken, hanem online elérhető, nagy felbontású fényképmásolatok segítségével tudtam tanulmányozni.

Ennek a munkának az eredményeképpen mostanáig a jelentős részét feldolgoztam a Szepességre vonatkozó, eredetiben, átiratban vagy másolatban fennmaradt okleveleknek. Amennyire azt a szakirodalmi és levéltári jegyzékek alapján meg lehet ítélni, a gyüjtés jelenleg a korai időszakra vonatkozóan már közel teljesnek mondható, ami a megye esetében az Anjou-kor végéig terjedő időszakot jelenti, ${ }^{5}$ ugyanakkor jelentős mennyiségü adatom gyült össze a 16. század első negyedéig terjedően is, valamint kiegészítésképpen kora újkori, de nem okleveles forrásokat (különböző adóösszeírásokat) is feldolgoztam (vö. KENYHERCZ 2014, 2015).

Mielőtt a vizsgálatok filológiai tapasztalatainak a bemutatására ténylegesen rátérek, szeretnék néhány számadatot bemutatni a Szepességre vonatkozó oklevelekkel kapcsolatban. Ezekkel azt igyekszem szemléltetni, hogy Szepes vármegye esetében mekkora az az adatmennyiség, amivel a középkorra vonatkozóan számolni lehet.

E tanulmány írásának az időpontjáig 4041 oklevél helynévi anyagát dolgoztam fel. Ebből 2791 irat eredetiben, 1250 pedig korabeli vagy későbbi átiratban, vagy pedig csak újkori másolatban maradt fenn. Az időbeli eloszlás tekintetében az Anjou-kor végéig 2665, az Anjou-kor végétől Mohácsig 1376 oklevél szórványai kerültek bele az adatbázisba. Mindezek alapján összesen 29.356 helynévi, pontosabban hely megnevezésére, azonosítására vonatkozó adat áll a rendelkezésemre.

\footnotetext{
${ }^{4}$ Különösen a kései Anjou-kortól kezdődően igaz mindez. A megelőző időszakra vonatkozóan a RegArp. vagy az AOklt. kötetei, valamint a CDES. és a RegSlov. a jelentősebb részét lefedik a megmaradt okleveleknek. Ezeken túl meg lehet még említeni egy-egy családi levéltár anyagát célzó forráskiadást is, amelyek között néhány nyelvészeti szempontból is hasznos és pontos forrásnak bizonyul (pl. FEKETE NAGY 1930, 1931). Az azonban hozzátartozik mindehhez, hogy az általam érvényesített szempontrendszer, amelyekről írásomban szólni fogok, leginkább az oklevelek közvetlen tanulmányozása révén formálódott, s elsősorban úgy is érvényesíthető.

${ }^{5}$ A korszakhatár meghúzása praktikus, ugyanakkor önkényesnek tekinthető. A vármegye benépesülése, középkori birtok-, illetve településrendszerének a kialakulása szempontjából azonban mégis azt lehet mondani, hogy eddig az időpontig a legtöbb középkori gyökerekkel rendelkező település kialakult.
} 
Ezeknek az időbeli eloszlása a következő: az Anjou-kor végéig 13.609, az Anjoukor végétől Mohácsig 15.747 helynévi vagy helyet jelölő adat gyült össze. ${ }^{6}$

Ezeknek a számoknak az értelmezéséhez az is hozzátartozik, hogy a Szepesség területén viszonylag későn kezdődött meg a vármegye megszervezése (lásd többek között FeKETE NAGY 1934: 9-51, KMTL. Szepes(ség), KRISTÓ 1988: 393-395, ZsOLDOS 2001), s ezzel összefüggésben az okleveles gyakorlat is később terjedt el, mint más területeken (vö. FEKETE NAGY 1934: 53-55). Az első két oklevél, amelyet a vármegyére szoktak vonatkoztatni, 1198-ra datálható, de a kettő közül az egyik biztosan hamis (vö. SCHMAUK 3-4, CDES. 1/99-100, RegArp. 1/1: 54, KARÁCSONYI 1902: 10-11), a másik pedig vélhetően nem a vármegye nevét tartalmazza, hanem csupán a benne szereplő név hasonlósága miatt hozták korábban tévesen összefüggésbe vele (vö. Df. 248310, CDES. 1: 99, KARÁCSONYI 1901: 1050, RegArp. 1/1: 54, HOMZA 2009: 126, LABANC-GLEJTEK 2015: 12-18). A vármegyéhez kapcsolható első hiteles oklevél 1209-ben keletkezett, igaz, ez csak egy 1246-os átiratban maradt fenn (vö. D1. 68752, RegArp. 1/1: 78-79, illetve RegArp. 1/2: 252). A korai iratok között említhető még egy 1216-os eredeti oklevél, amelyben viszont — az ispánjának említése kapcsán csak a vármegye neve adatolható (vö. Dl. 74, RegArp. 1/1: 101). Egy 1217-es szintén eredetiben megmaradt oklevélben azonban már egy a vármegye területével kapcsolatos birtokügyletet is megörökítettek (vö. D1. 79, RegArp. 1/1: 103). Általánosságban viszont az mondható el, hogy — a vármegye benépesülésével összefüggésben - Szepesre vonatkozóan igazán csak a tatárjárás utáni időkben, de leginkább a 13. század végétől kezdődően keletkeztek nagyobb számban oklevelek.

A Szepességhez köthető okleveles források nyelv- és névtörténeti jelentőségüket és terjedelmüket illetően meglehetősen vegyes képet mutatnak. Kései keletkezésükből adódóan már nem számítanak egyedinek a korukban, s így nyelvtörténeti szempontból egyenként nem mérhetök a magyar nyelvtudományban kiemelt figyelmet érdemlő korai nagy okleveleinkhez. Vannak köztük ugyan

${ }^{6}$ Feltünő, hogy noha az Anjou-kor utáni időszakból feleannyi oklevelet dolgoztam fel, ám bennük összesen mégis bő kétezerrel több szórvány található, mint az azt megelőző korszakból származó oklevelekben. Mindazonáltal az adatsürüség növekedéséből (5,1, illetve 11,4 helynévi szórvány/oklevél) önmagában nem igazán lehet releváns következtetéseket levonni. Ez az arány ugyanis nem csupán a megye betelepülésének az ütemével van összefüggésben, hanem emellett jelentős mértékben befolyásolták az adott időszak történeti és birtoklástörténeti körülményei, illetve az ezekhez kapcsolódó okleveles ügyek jellege is. Nem elhanyagolható például az adatsürüség szempontjából, hogy hány érintett fél vett részt egy adott ügyben, s hogy annak a jellege igényelte-e határok leírását stb. Ráadásul az Anjou-kor és Zsigmond-kor fordulójától kezdve bizonyos típusú eljárások kapcsán a Szepességre vonatkozóan is megnőtt a kiadott oklevelek terjedelme, mégpedig jellemzően amiatt, mert ebben az időszakban terjedt el az a hivatali gyakorlat, hogy egy-egy ügy korábbi szakaszainak vagy okleveleinek a részletesebb tartalmi összefoglalását is belefogalmazták az oklevelekbe, s ez szükségszerüen maga után vonta az iratokban a helynévi elemek számának a növekedését is. 
hosszabb terjedelmű iratok is, de ezek főként a 14. század végétől kezdődően jelennek meg (vö. 6. lábjegyzet). Ellenben rengeteg az olyan pár soros, örökösödési, adásvételi vagy valamilyen peres ügyet tartalmazó oklevél, amelyeknek sem a történeti, sem a nyelvtörténeti forrásértéke nem különösebben kiemelkedő. Mindezek ellenére mégis azt gondolom, hogy ezek nyelvészeti feldolgozása (koránt)sem haszon nélküli, hiszen éppen az okleveles források értelmezésének a szempontjából - erről hamarosan részletesebben is szólok — ezeknek az okleveleknek is felértékelödik a jelentősége.

Az mindenesetre elmondható, hogy az így összeállt adatmennyiség már túlmutat azon, ami egy vármegyei történeti-etimológiai helynévszótár elkészítéséhez szükséges. Ráadásul egy ilyen speciális, egyetlen területre vonatkozó adatgyüjtés - jellegéből adódóan — önmagában tágabb névtörténeti összefüggések feltárására nem is alkalmas. Más szempontból viszont egy-egy szükebb terület helynévi adatainak az ilyen mélységü vizsgálata véleményem szerint sok olyan tapasztalattal is járhat, amely a nyelvtörténeti kutatások más szintjein — elsősorban a helyesírás-történet és a nyelvi érintkezések vizsgálata kapcsán — jól hasznosítható. Ám mivel a forrásadottságok tekintetében az egyes országrészek és vármegyék kisebb-nagyobb mértékben ugyan, de különböznek egymástól, ${ }^{7}$ hangsúlyozni kell, hogy az adatok értelmezésével kapcsolatban az alábbiakban megfogalmazott megfigyeléseim — noha azt gondolom, hogy egy általános képbe is jól beilleszthetők — egyáltalán nem biztos, hogy önmagukban más területek esetében is mindenféle adaptáció nélkül megállnak.

\section{A középkori oklevelek nyelvtörténeti forrásértékének kérdései}

A következőkben néhány olyan egymással szorosan összefüggő problémát tárgyalok, amelyek a Szepes vármegyére vonatkozó oklevelek és a bennük megőrzött helynévi szórványok nyelvészeti elemzése kapcsán jellemzően felmerülnek. Olyan kérdések ezek, amelyek nemcsak az okleveles adatok értelmezését, de az azok alapján elvégzett további vizsgálatokat, $\mathrm{s}$ végső soron a terület nyelvietnikai rekonstrukcióját is érintik.

\subsection{Az oklevelek fennmaradása és a nyelvi rekonstrukció lehetőségei}

A bevezetőben már utaltam rá, hogy a középkori oklevelek helynévi szórványai alapján csak egy szükségszerúen töredékes képet tudunk megalkotni az általuk közvetített korabeli nyelvi valóságról. Ezt a töredékességet hagyományosan az oklevelek fennmaradásának a problémájával szokták összefüggésbe hozni. S valóban, az évszázadok történelmi eseményei, természeti csapások, tüzesetek,

\footnotetext{
${ }^{7}$ Az eltérő földrajzi adottságok, a birtoklástörténeti és a történelmi háttér, a nyelvi-etnikai viszonyok, valamint a források mennyisége és jellege mind-mind befolyásolhatják az összképet.
} 
fosztogatások, de még a régi korok tárolási sajátságai (beázás, penész, kártevők stb. rongálásai) is mind olyan tényezők voltak, amelyek az oklevelek fennmaradását meglehetősen esetlegessé tették, $s$ területenként és koronként változó mértékben ugyan, de hozzájárultak az oklevelek pusztulásához. ${ }^{8}$ Emellett azonban azt is érdemes kiemelni, hogy egyes oklevéltípusok eleve nem az örökkévalóságnak készültek. A birtokadományokról vagy kiváltságokról szóló okleveleket azok tulajdonosai nagy gonddal őrizték, átiratták, lemásoltatták, hogy biztosan megmaradjanak, ugyanakkor más iratok csak az eljárások bizonyos fázisaiban voltak fontosak. Ilyenek voltak például a királyi vagy más országos hatóságtól származó parancsok, amelyek a címzett hiteleshelyen a parancs végrehajtása és a jelentésbe való átírás után már nem bírtak további érvénnyel. ${ }^{9}$ A korai évszázadokból nem is maradtak meg ilyen mandátumok eredeti példányai a szepesi káptalanban, $\mathrm{s}$ a 15-16. századtól kezdve sem mint értékes iratokat őrizték meg őket, hanem jellemzően ezek hátlapjára írták a parancsra adott hiteleshelyi jelentés fogalmazványát (vö. SZENTPÉTERY 1930/1995: 18).

Ugyanakkor nemcsak az oklevelek fennmaradása, hanem már eleve azok keletkezése is sok esetben esetlegesnek mondható. Érdemes figyelembe venni, hogy a Kárpát-medence egészét tekintve - föként a vármegyerendszer megszervezésével és egyes területek benépesülésével összefüggésben — az okleveles gyakorlat elterjedése nem azonos időben és ütemben történt. Így például Szepes vármegyében - amellett, hogy a megye egy része még sokáig lakatlan volt - a tatárjárás elötti néhány évtizedből nem pusztán azért nem maradtak fent nagyobb számban helynévi adatok, mert az oklevelek elpusztultak, ${ }^{10}$ hanem egyszerüen erre a területre vonatkozóan a 13. század első feléig nem keletkeztek nagyobb számban oklevelek. S nem pusztán az okleveles gyakorlat elterjedésének az üteméből adódóan, hanem ehhez talán Szepes vármegye esetében az is hozzájárulhatott, hogy a korai időszakban nem feltétlenül merültek fel nagyobb számban olyan ügyek (birtokadományok, perek, királyi kiváltságok stb.), amelyek miatt okleveleket kellett volna kiállítani (vö. FEKETE NAGY 1934: 53-55).

\footnotetext{
${ }^{8}$ ENGEL PÁL egy helyütt egészen pesszimista becslést közöl a nevek egy speciális körére, a korai várak megnevezésére vonatkozó adatokkal kapcsolatban. Véleménye szerint ugyanis az 1320 előtt épült várakról szóló okleveleknek pusztán 1-2\%-a maradt ránk (vö. 1987/2007: 17, idézi KoVÁCS H. 2019: 16).

${ }^{9}$ Ritkábban ugyan, de a kancellária kiadott ún. általános parancsokat is, amelyek tovább, általában egy évig voltak érvényesek, de egy-egy mandátum jellemzően mégis egy ügyre vonatkozott csak (vö. ECKHART 1914/2012: 143).

${ }^{10}$ Volt ilyen is természetesen. A tatárjárás okozta károk mellett (vö. FeKETE NAGY 1934: 55) a Szepességre vonatkozóan megemlíthető az 1280-as évek második felében — vélhetően a Jakab szepesi prépost és IV. László király között megromlott viszony következében - a szepesi vár nyögér őrei által végzett pusztítás is, amely során a káptalan számos irata elpusztult, s a pecsétje is eltünt (vö. BujÁK 2015: 18, 25, 33, SzÖCs 2010: 29-30).
} 
Magától értetődő ugyan, de ehhez hozzátartozik az is, hogy egy helynév csak akkor került bele egy oklevél szövegébe, ha valamilyen jogi eljárás során ennek a szüksége egyáltalán felmerült. Nem minden esetben adódott azonban olyan körülmény, szándék vagy szükség, hogy egy nevet — különösen egy határnevet annak keletkezése után rögtön írásban is rögzítsenek. Így jócskán előfordulhattak olyan esetek is, amikor egy helynév első oklevélbeli feltünéséhez képest már régebb óta létezhetett, de sem jogvita, sem örökösödési harc, sem eladás kapcsán nem került elő, ráadásul határjárások pontjaként sem említették, s ennek megfelelően alig maradt fent adata a régebbi időkre vonatkozóan. Olykor azonban történeti vagy névtani érvek alapján mégis sejteni lehet, hogy egy adott hely megnevezése évekkel, évtizedekkel, de akár egy-két generációval korábban keletkezett, mint ahogy az első írásoss említése megtörtént.

A történeti-birtoklástörténeti háttér ismeretéből adódóan a mára már eltünt Becsfalva keletkezésének kapcsán például felmerülhet, hogy az 1258-as első említésénél korábbi kialakulásúnak kell tekintenünk, ugyanis ekkor már 14, egymással nem rokon család birtokolja, ami FEKETE NAGY ANTAL szerint azt mutatja, hogy egy ideje már létező birtokról volt szó (vö. Df. 209774, FEKETE NAGY 1934: 150-152). De 1268-as feltünésekor ${ }^{11}$ Baldmár (Harichovce) is mint egyházzal rendelkezö, tekintélyes helységként jelent meg, ami szintén a település régebbi fennállását sejteti (vö. Df. 272706, FEKETE NAGY 1934: 102). Az, hogy egy településnek az első okleveles feltünésekor már temploma volt, már önmagában is a település korábbi alapítására utal, mint például azt FEKETE NAGY Szentandrás (Hôrka-Ondrej) és Szentlászló (Spišský Štvrtok) kapcsán a patrocíniumi eredetü nevük alapján gondolja (vö. 1934: 68, 191-195), vagy pedig Busóc (Bušovce) esetében, ahol első alkalommal a település neve a plébánosának említésekor került elő (vö. Dl. 41397, FEKETE NAGY 1934: 233). Bár hozzá kell tenni, hogy egy kisebb település templomának a megépítése nem tartott már a 13. században sem egy-két évnél tovább, amit Vlazsinópatak (Ol’šavica-Podproč) esete is példáz. Neve ugyanis mint birtok, föld és erdős terület már 1314-ben is több forrásban feltünik, azonban még 1316-ban is újonnan betelepült falunak nevezi egy oklevél szövege, viszont a forrásból kiderül az is, hogy ekkor már volt papja, ami feltételezi, hogy volt temploma is (vö. Dl. 63635, Dl. 83168, Dl. 83169, Df. 272695, illetve FEKETE NAGY 1934: 158-159).

Más esetekben névtani okok miatt lehet az első okleveles említésénél korábbinak tekinteni egy település kialakulását. Ilyesfélére hozható példaként az oklevelekben csak 1326-ban felbukkanó Ófalu (Spišská Stará Ves) esete (vö. Dl.

${ }^{11}$ Ez az oklevél eredetiben nem, csak a Df. 272706-os szám alatt található, 1427-ben készült oklevélbe átírva maradt fenn, amelyben viszont a datálás PETER LABANC szerint tévesen vonatkozik 1278-ra, s az érvei alapján valódi kelete hihető módon 1268-ra javítható (2013: 26). 
40492). A szepesi krónikák és régi történetírók — vélhetően a neve alapján — egészen olyan időkig visszaviszik a település keletkezését, amikor a területen még biztosan öserdő volt. Kialakulása FEKETE NAGY szerint a Berzeviczy család birtoklásával függ össze. S mivel a család 1290-es osztálylevelében a falu még nem szerepel, így véleménye szerint alapítása ennél a dátumnál későbbre tehető. A rendelkezésére álló adatok alapján azt feltételezi, hogy a település 1308 után alakulhatott ki, ${ }^{12}$ ami viszont még szepesi viszonyok között sem túlságosan korai időszak ahhoz, hogy Ófalunak nevezzék el. A névadás motivációja FEKETE NAGY szerint így inkább az lehetett, hogy valamelyik környező faluhoz képest régebbi telepítésről van szó, s nem általában az egész megyére vonatkozóan (vö. FEKETE NAGY 1934: 238-239). Ha megnézzük a környező települések első elöfordulásainak az idejét, pusztán az oklevelek alapján sajnos ezt ugyanúgy nem tudjuk igazolni, mint azt, hogy a település kialakulása egészen a vármegye kezdetének az idejéig megy vissza. Ha csupán azokat a településeket vesszük számba, amelyek közvetlenül Ófalu környezetében találhatók, akkor azt látjuk, hogy valójában Ófalu tünik fel ezek közül a legkésőbb. Lehnic (Lechnica) 1319-ben bukkan fel, ekkor már mint kialakult falu, amit a menedékkövi barátok kapnak meg kolostoralapításra (vö. Dl. 31067, AOklt. 5: 179, FEKETE NAGY 1934: 240). Katzwinkel (Kacwin), Nedec (Niedzica) és Frankvágása (Malá Franková és Vel'ká Franková) egy 1320-as oklevélben egyszerre tünnek fel (vö. Dl. 68821, AOklt. 5: 348). Ezek közül Frankvágására mint Frank mester falujára ráadásul már korábban, 1314-ben történik latin nyelvü utalás egy oklevélben (vö. D1. 70456, AOklt. 3: 370-371). Az Ófaluhoz legközelebb eső Mátyásvágása (Matiašovce) neve pedig Ófaluval éppen egy oklevélben kerül elő elsőként (vö. Dl. 40492, AOklt. 10: 296-298).

A legtöbb esetben azonban sem közvetlen, sem közvetett háttérinformációk nem állnak rendelkezésünkre, így ezek hiányában egy név keletkezését vagy pedig a név hangszerkezeti-szerkezeti változását többnyire kénytelenek vagyunk a keletkezésük és fennmaradásuk miatt esetlegesen és töredékesen ránk maradt adatok segítségével vizsgálni. Ez a körülmény pedig különösen nagy jelentőséget kap akkor, amikor nem pusztán egy név etimológiáját keressük — például az Ófalu, Szentandrás vagy Szentlászló nevek esetében ez nem is különösebben nagy kihívás -, hanem a néveredet magyarázata csak egy lépés egy korszak vagy terület nyelvi-etnikai rekonstrukciója során.

${ }^{12}$ FeKeTE NAgY e dátum meghatározásakor azt veszi alapul, hogy a Berzeviczy család egyik öse, Kokos mester 1308-ban lényegében Ófalu területét jelöli meg egy oklevélben mint egy berket, amit betelepülésre elajándékoz (vö. D1. 1723). Lásd ehhez még PETER LABANC véleményét is (2020: 29), aki - JÁN ENDRÖDI munkájára hivatkozva - szintén ehhez a birtokügyhöz köti Ófalu kialakulását. Egyébként éppen 2008-ban tartottak egy konferenciát a település 700. évfordulója alkalmából, aminek az előadásai tanulmánykötetben is megjelentek (MALOVCOVÁ szerk. 2008). 


\subsection{Az oklevelek szórványainak nyelvi hüsége}

Az oklevelek helynévi adatainak elemzése kapcsán elsőrendü kérdés, hogy azok révén mi is az tulajdonképpen, amit valójában vizsgálni tudunk. A következő pontokban néhány olyan tényezőt szeretnék a szepesi források tanulságai alapján körüljárni, amelyek véleményem szerint lényegesen befolyásolják azt, hogy az okleveles források mit engednek látni abból a nyelvi valóságból, amelyre a nyelv- és névtörténeti kutatások irányulnak.

\subsubsection{Az oklevelek jogbiztosító szerepének nyelvi vonatkozásai}

Az oklevelek nyelvi hüségének a megítélése kapcsán soha nem hagyható figyelmen kívül az az egyébként magától értetődő körülmény, hogy a különböző hatóságok által kiadott oklevelek, noha a nyelvtörténészek számára kedves és böséges forrásai a régi nyelvnek, nem a nyelvi adatok megőrzésének céljából születtek. Az oklevelek ugyanis csak az adott ügyben érintett személyek és helyek azonosíthatósága miatt tartalmaztak helyneveket. Ebből adódóan viszont — mint ahogy az ma már a szakirodalomban elfogadott nézetnek tekinthető — az oklevelek névhasználata a jogbiztosító szerepükkel összefüggően alapvetően hüen tükrözi a korabeli állapotokat, hiszen a bennük szereplő személyek és helyek azonosíthatósága nélkül jelentősen veszítettek volna jogi érvényükből (vö. HoFFMANN-RÁCZ-TÓTH 2018: 43-44). Kétségtelen, hogy fiktív neveket az oklevél megszövegezői nem költöttek (vö. HOFFMANN-RÁCZ-TóTH 2018: 48, KRISTÓ 2000: 27). Különösen érdekes e tekintetben, hogy még a hamis oklevelek sem válnak el — többnyire a hamisítás korának (vö. HOFFMANN-RÁCZ-TÓTH 2018: 47) - a nyelvi valóságtól, hiszen a hamis szándék érvényesítése is az egyébként létező nevek azonosító funkcióját használta ki, ugyanis a hamisítás jellemzően nem a nyelvi valóság megmásítására irányult, hanem például a birtokjogi körülményekére. ${ }^{13}$

A középkori oklevelek névhasználatának nyelvi hüségével kapcsolatosan elmondható az is, hogy a jogbiztosítás, s ennek megfelelően egy személy vagy hely jogi értelemben vett azonosíthatósága szorosan összefüggött az oklevélbe beleírt nevének a nyelvi megformáltságával is. Az okleveles gyakorlatnak ez a sajátsága többnyire azonban csak indirekt módon ragadható meg, mert a fentiek fényében érthető okokból ez eleve az oklevelek kiállításának alapvető és szükségszerü kívánalmai közé tartozhatott, így külön megjegyzés vagy reflexió erre vonatkozóan az oklevelek szövegében nem is jelenik meg. Ugyanakkor ha nem is túl nagy számban, mégis vannak adatok, amelyek arra utalnak, hogy a nevek formájának a kérdése az ügyek intézése során valóban nem számított lényegtelennek, ám ez

${ }^{13}$ Ezen a sajátságon alapszik SzŐKE MELINDA hamis oklevelek nyelvészeti elemzésére alkalmazható módszere is, amit a szerző legrészletesebben A garamszentbenedeki apátság alapítólevelének nyelvtörténeti vizsgálata címü 2015-ben megjelent könyvében fejt ki. 
az általam feldolgozott anyagban jellemzően egy-egy utólagosan elvégzett vagy az átírás során tett javításból derül ki csupán. ${ }^{14}$ Ezek közül érdekes adalékként szolgál egy 15 . századi ügy, amely során egy írnok utólagos feljegyzése hívja fel a figyelmet a nevek formája és az azonosíthatóság összefüggéseire. Zsigmond király 1432-es oklevelében Nicolaus de Sthetlak néven említenek egy királyi embert, akinek a nevét a szepesi káptalan az ugyanebben az évben kiadott jelentésében Nicolaus de Stheplaka formában használta. Zsigmond király 1435-ös oklevelének - amelyben átírja a szepesi káptalan, illetve az abban átírt saját oklevelét is - a felhajtott részén (plica) található egy feljegyzés, amiből kiderül, hogy a kancelláriai írnok jónak látta ezt a számára ellentmondásnak tűnő, esetlegesen félreértésekhez vezető kettősséget feloldani a queratur Stetlok vel Steplaka megjegyzéssel (Dl. 12570, vö. SZENTPÉTERY 1942: 421).

Igaz, hogy egy személynév kapcsán, de szintén a nevek jogbiztosításban betöltött szerepét érezhette a Berzeviczy család két őse, János mester és fivére, Miklós is, amikor 1335-ben a szepesi káptalanhoz fordultak a következö ügyben: birtokukban volt egy 1289-es keltezésü oklevél, amelyben a Tárca nevü birtok (Torysa) határjárásakor a határokat hitelesítő Görgey-ős Theodoricus latin névalakkal van megnevezve, ám mikor az oklevelet apjuk 1323-ban az országbíró előtt felmutatta, annak magyar írnokai az átírás során a kérdéses nevet Thyadar vagy Theodorus formában használták. A káptalanhoz forduló birtokosok kérték tehát a káptalan állásfoglalását ezzel a névértelmezéssel kapcsolatban, amire a káptalan ki is állított egy oklevelet, amely alapján az álláspontjuk úgy értelmezhetö, hogy a Theodorus-nak magyarul Thyadar (Tivadar), a Theodoricus-nak viszont Detricus (Detre) felel meg (vö. FEJÉRPATAKY 1918, illetve az idézett oklevelet lásd D1. 68826 szám alatt). FEJÉRPATAKY LÁSZLÓ így foglalta össze a problémát: „Fontos érdekek füződhettek a Theodoricus név helyes értelmezéséhez, mert a tárczai határjárásnál a határok mentébe beléegyező Görgey-családbelinek neve Detricus formában lehetett a felvidéken közismert." (i. m. 172). Így az, hogy a kancellária magyar írnokai az eredeti oklevélben szereplö Theodoricus nevet Tivadar és Theodorus formában fordították le, illetve írták át, a Detre nevü személy azonosítását, s ezáltal a birtok határainak az igazolását nyilvánvalóan egy per során problematikussá tehette. A birtokos család a kérdésben legilletékesebb hiteleshelynek, a szepesi káptalannak az oklevelével azonban már jó esélyekkel fordulhatott utólagos helyesbítéséért a királyi kancelláriához az 1323-as oklevél névhasználatával kapcsolatban (vö. i. m. 172-173).

Azt hiszem, ez az ügy önmagában is jól példázza azt, amit a nevek jogbiztosításban betöltött szerepével kapcsolatban gondolunk, azonban egyben már átvezet

${ }^{14}$ Efféle ügyekkel egy korábbi munkámban részletesen foglalkoztam, elsősorban az oklevelek átírási gyakorlatának a fényében, ugyanakkor azt gondolom, az elemzett példák egyben az oklevelek névhasználatának az itt tárgyalt sajátságát is mutatják (vö. KENYHERCZ 2016). 
a kérdéssel kapcsolatos következő problémához, mégpedig az oklevelek latinizáló névhasználatának a gyakorlatához. A nevek azonosítást lehetővé tevő szerepéről elmondottaknak ugyanis látszólag ellentmond az, hogy bizonyos típusú neveket részben vagy egészben latinra fordítva vagy latinosított formában használtak az egész középkoron át. ${ }^{15}$ Noha a tárcai birtokügy arra utal, hogy ez alkalmanként problémákhoz is vezethetett, a latinizálás gyakorlatának elterjedtségében - amit nyilvánvalóan nem pusztán a latin nyelvbe foglalás grammatikai kényszere eredményezett — mégis az mutatkozik meg, hogy a latinizáló névhasználat alapvetően mégsem érintette az iratok jogi érvényét, pedig ennek az eljárásnak az eredményeképpen a személyek és helyek nevei éppen olyan formában kerültek bele az iratokba, ahogyan a hétköznapi, vulgáris nyelvhasználatban biztosan nem fordultak elö. Az ugyanis, hogy egy személyt Petrus formában vagy pedig egy települést Foro Caseorum néven említett az oklevél szövege, jellemzően nem eredményezte azt, hogy a Péter nevü személy vagy a Késmárk nevü város jogbiztonsága ebből adódóan bármilyen mértékben is veszélybe került volna, hiszen az azonosíthatóságuk — hivatali szinten mindenképpen — a latinizált vagy latin névváltozat használata ellenére is megmaradt, különben nem használták volna ezeket a neveket latin formájukban. E kettősség kapcsán HoFFMANN, RÁCZ és TÓTH úgy látja, hogy a latinizálás gyakorlata azonban mégiscsak bizonyos korlátok között müködhetett, mivel e névformák a jogbiztosító szerepük tekintetében nem rendelkeztek a vulgáris nyelvi megnevezések minden elönyével (vö. 2018: 52). Azt gondolom, hogy az imént bemutatott Theodoricus-ügy is noha nem helynevet, hanem személynevet érintett — erre utalhat.

Ez az ellentmondás, ami egy név nyelvi megformáltságának az azonosításban betöltött jelentősége, illetve a név nyelvi megformáltságába való tudatos beavatkozás között olykor megfigyelhető, elvezet minket a középkori okleveles szórványok vizsgálatának egy másik fontos kérdéséhez. Ahhoz tudniillik, hogy az oklevelek névhasználatában miként tükröződnek az okleveles gyakorlat névhasználatra vonatkozó normatörekvései, illetve a gyakorlat mögött meghúzódó korabeli nyelvi presztízsviszonyok. Azt gondolom ugyanis, hogy azok a korlátok és keretek, amiket a latinizálás kapcsán feltehetünk, más összefüggésekben, eltérő mértékben és különböző módon, de a magyar nyelvre vonatkozóan is feltételezhetők. Ezt a kérdést - noha egyelőre még sok bizonytalanság övezi azért is tartom különösen fontosnak felvetni, mert e szempontok érvényesítésével a szepesi okleveles anyag bizonyos anomáliái is jól magyarázhatónak tünnek.

\subsubsection{Nyelvi presztízs hatása az oklevelek névhasználatára}

Megítélésem szerint a középkori oklevelek névadatainak az értékelését döntően befolyásolja az, hogy miként ítéljük meg a korabeli nyelvi presztízs okleveles

${ }^{15}$ A tulajdonnevek latinizálásának kérdéseihez lásd többek között HoFFMANN 2004, 2010, HoFFMANN-RÁCZ-TóTH 2018: 52-96, SZENTGYÖRGYI 2010, SZÖKE 2008, 2013. 
névhasználatban megmutatkozó hatását. HOFFMANN ISTVÁN, RÁCZ ANITA és TÓTH VALÉRIA véleménye szerint ugyanis a középkori Magyarország nyelvi presztízsviszonyai az oklevelek helynévi szórványainak a használatában is tükröződnek (vö. 2018: 51). Az közismert, hogy a középkori magyar királyság legnagyobb presztízsü vulgáris nyelve a magyar volt, s ez a presztízs a magyar nyelv hivatalos nyelvhasználatban betöltött státuszát is nyilvánvalóan érintette (vö. i. m. 50-52, MAREK 2015: 153). A szepesi okleveles források feldolgozásakor így az egyik legizgalmasabb kérdésnek azt látom, hogy a magyar nyelv presztízsének a hatása - természetesen az oklevelek jogbiztosító szerepéből adódó korlátok között, mint ahogy azt a latin nyelvü vagy latinizáló névhasználat kapcsán az előzőekben már érintettem - akár a névváltozat kiválasztásában, akár a név nyelvi hangtani-alaktani szerkezetébe való oklevélírói beavatkozásban megnyilvánult-e, $\mathrm{s}$ ha igen, ez a hatás miként mutatható ki. Ennek az igencsak összetett kérdésnek itt egyetlen összefüggését szeretném megragadni.

A középkori Szepes vármegye nyelvi-etnikai viszonyainak a rekonstruálása nem egyszerü feladat, ám az bizonyosnak látszik, hogy a térségben a középkorban a három meghatározó nyelvi-etnikai csoport a magyar, a szláv és a német volt. ${ }^{16}$ Ám az oklevelek névhasználatának a sajátságai alapján olykor felmerül a gyanú, hogy az írnokok mintha nem feltétlenül törekedtek volna a helynévhasználat nyelvi sokszínüségének a pontos visszaadására. Bizonyos esetekben ugyanis az látszik, hogy az oklevelek névalakjainak a leírásakor nem pusztán az befolyásolta az írnokokat, hogy az adott időszakban és területen melyik változat volt a hétköznapi névhasználatban a legelterjedtebb, hanem az, hogy a kevésbé magas presztízzsel rendelkező nyelvü, s ebből adódóan kevésbé hivatalosnak tekintett névalakok — vélhetően a névhasználói közösség létszámától függetlenül — a Szepességben egyszerüen nem kerültek bele az iratokba. HoFFMANN ISTVÁN, RÁCZ ANITA és TÓTH VALÉRIA úgy véli, hogy a presztízs szempontjából periférikus nyelvek helynévalakjai csakis ott kerülhettek be az oklevelekbe, ahol a magasabb presztízsű nyelveknek a használata egyáltalán nem volt jellemző (vö. 2018: 52).

A fentiekre legkézenfekvőbb példaként Szepes vármegye nevének az esetét említhetjük. A területen már a vármegye megszervezésének idejétől, a 12-13.

\footnotetext{
${ }^{16}$ Ez nem csupán az okleveles helynévanyagból következtethető ki, hanem az oklevelek latin szövege is utal olykor a vármegye vagy egy-egy település lakosságának etnikai hovatartozására. Lásd pl. Dl. 63605, Dl. 71613, Dl. 74779, Df. 281698, de különösen értékes forrás e tekintetben Erzsébet királyné 1279-es oklevele, amelyből egy birtokjog igazolása kapcsán kiderül, hogy a vizsgálat során nemcsak az írott forrásokból, hanem a Szepességben élő németektől, magyaroktól és szlávoktól nyert információkat (ab omnibus Theotonicis, Hungaris et Sclavis in eadem terra Scypus degentibus) is felhasználták (vö. Df. 272386, RegDuc. 80-81). Említést érdemel továbbá Loránd szepesi comes 1274-es oklevele is, amelyben korabeli szepesi nemesek név szerinti felsorolása kapcsán a szöveg helyenként utal azok német, szláv vagy magyar voltára (vö. Df. 264119, RegArp. 2/2-3: 95-97).
} 
századtól kezdve különböző etnikai csoportok — szlávok, magyarok, később németek és újlatin népek - éltek együtt egészen a középkor végéig. Ennek megfelelően a terület megnevezésére több névváltozat is létezett. Magyarul Szepes-nek, szlovákul és lengyelül Spiš/Spisz-nek, németül Zips-nek nevezték. Azonban a hivatalos iratokban az egész középkoron át csak a magyar, ritkábban a német változat, illetve az e kettőn alapuló latinizált formák adatolhatók, a magyar királyság területén keletkezett oklevelekben nyoma sincs a szlávos szerkezetü névformának. Az okleveles adatok hiánya azonban önmagában nem feltétlenül jelenti azt, hogy a régiségben a Spiš névforma nem is létezett volna a szláv közösség használatában, sőt etimológiai szempontból az sem kizárt, hogy a szláv változat akár az elsődleges is lehetett (vö. KENYHERCZ 2018). Egyszerüen arról lehet szó, hogy ebben az időben a szláv nyelvek presztízse a magyar királyság területén alacsony volt, így az oklevelekbe a szláv névalak — föleg, ha az rendelkezett magyar vagy német névpárral - egyszerüen nem került bele (vö. HoFFMANN 2007: 91, KENYHERCZ 2013b). Esetünkben ezt a feltételezést megerősíti, hogy a szláv névalak létezését egy külföldi, nem okleveles forrásból egyébként egyértelmüen bizonyítani is lehet, ugyanis II. Boguchwał Lengyelországban keletkezett 13. századi krónikája tartalmazza a terület nevének szláv változatát Spis $\sim$ Spys formában (vö. KSA. 32). ${ }^{17}$

Mindezek fényében, úgy gondolom, érdemes más szepesi $-\mathrm{s}$ általában a többnyelvü területeken használatos - nevek etimológiáját és történetét is az okleveles névhasználat ezen joggal feltehető sajátságának a fényében vizsgálni. A Szepesváralja (Spišské Podhradie) környékén fekvő Hotkóc (Hodkovce) település adatai is vélhetően hasonló eljárást tükröznek. A hely régi adatai a következők:

Hotkóc: 1292: de v. Hodchouch (Dl. 39430); 1293/1337/1378: Hodcouch, v. Hodkouch, v. (Dl. 39634); 1342: Hodchouch, v. Hodcouch, v. (Dl. 39657); 1412/1448/1462: Hothkoncz [o: Hothkoucz] (Df 274357); 1421: H[odk]olch (Dl. 43493); 1438: Hotkol [o: Hotkoch] (Dl. 39733); 1444: Hotkoch, de (Dl. 39750); 1471: Hothkolcz (Dl. 60821); 1472: Hotkocz (Dl. 39770); 1472: Hotkocz (Dl. 39772); 1474: Hotkolcz (Dl. 39774); 1538: Hathkocz (E 158/35: 5-42); 1564: Hotkocz (E 158/35: 271-375); 1567: Hothkocz (E 158/36: 3-17); 1570: Hottkowcz (E 158/36: 3-17); 1593: Hotkocz (E 158/35: 438-459); 1598: Hotkowcze (E 158/36: 3-17); 1599: Hotkocz (UC. 117/77); 1635: Hottkocz (E 158/36: 50103); 1715: Hatkócz (N 78); 1808: Hotkócz vel Újmajor h., Hotkowce s. (Lipszky).

${ }^{17}$ Ez a krónika ugyan eredetiben nem maradt fenn, de több korabeli másolata bizonyítja, hogy a korszakban a térség neve szláv változatban is ismert és használatos volt (vö. KENYHERCZ 2018: 122). 
Az bizonyosnak tekinthető, hogy a név végső soron egy szláv *Hodkovec *Hodkovce formára vezethetö vissza, ami a magyarba átkerülve a névvég adaptációjával Hotkóc lett. Az etimológiai elsődlegesség ellenére a *Hodkovec *Hodkovce alak első biztos említése csak 1598-ból való. Azaz a név első megjelenését követő háromszáz évből egyáltalán nincs adatunk a magyar nyelvü változat etimonjaként feltételezett szláv névformára. Hotkóc esetében az is tudható, hogy a település - és ezzel együtt a név — nem nagyon lehet régebbi az 1292. évi első említésénél, ugyanis kialakulása a szepesi várföldek rendezésével függ össze, ami pedig a 13. század kilencvenes éveinek az első felére tehető (vö. FEKETE NAGY 1934: 147). Azaz a névre a létrejöttének pillanatától van adatunk, ami a nyelvi megformáltsága alapján szláv helynévképzővel alakult, azaz szláv eredetű, viszont a rá vonatkozó forrásokban ez a forma sokáig hiányzik, s csak a magyar fonológiai névpárja adatolható. Az -ovec/-ovce végződéssel alakult szláv nevekröl egyébként is elmondható, hogy az eredeti hangszerkezetet tükröző adatok jelentősebb számban legkorábban csak a 15. századtól kezdődően fordulnak elő az oklevelekben (vö. KENYHERCZ 2013a: 64, illetve 2013b: 39-40).

Azt gondolom, az ellentmondást — akárcsak a vármegye nevének az esetében — itt is a nyelvi presztízsviszonyok figyelembevételével oldhatjuk fel. A vármegye ezen részének a nyelvi viszonyai alapján igencsak valószínünek tünik, hogy a csak 1598-ban föltünő, ám etimológiai szempontból elsődlegesnek tartható Hodkovec Hodkovce névalak a létrejöttétől kezdődően többé-kevésbé folyamatosan használatban lehetett a területen, ám mégis azt látjuk, hogy az írnokok következetesen a név magasabb presztízsủ magyar párját, a Hotkóc-ot használták.

Az efféle esetek nem elszigeteltek a Szepességben, s maga az eljárás — ahogy erre már utaltam - egyértelmü hasonlóságokat mutat a helynevek latinizálásának a korabeli gyakorlatával. Mindenesetre az a kérdés nyitott marad, hogy a feltételezett szláv névhasználat mellett a magyar Hotkóc formát a fentiek fényében a ritkább, de magasabb presztízsủ változatnak, vagy a népnyelvben nem, hanem csak a hivatalosságban használt hivatalos névnek, esetleg mégis a gyakoribb variánsnak tekintsük-e.

Más hangsúlyokkal ugyan, de ugyanez a kérdés Szepes vármegye esetében a magyar és a német nyelvü nevek és névpárok viszonylatában is felvethető. Megfigyelhető ugyanis, hogy a 13-15. századi latin nyelvü oklevelekben föként csak a mikronevek szerepelnek németül, a települések nevei - ha azoknak volt magyar névpárja - akkor is magyarul fordulnak elö, ha az oklevelek szövege kifejezetten utalt arra, hogy a település vagy a környék lakossága német volt. Ez a sajátság annak a fényében még inkább lényegessé válik, hogy a 15. századtól a Szepességben már német nyelvü oklevelek is keletkeztek, melyekben viszont ugyanezek a települések már kizárólag német nevükön jelennek meg, magyarul — és latinul - sohasem (pl. Dl. 71530, F. 10/2: 89, valamint lásd még ehhez latin nyelvü oklevelek német másolatait is, úgymint Df. 258628, Df. 267845). 
Azaz úgy tünik, a Szepességre vonatkozó latin nyelvű oklevelekben a magyar nevek a németajkú lakosság — társadalmi és jogi helyzetéböl adódóan — magasnak mondható társadalmi presztízse ellenére is elsőbbséget élveztek a német névpárjukkal szemben. ${ }^{18}$

Azt gondolom, hogy az oklevelekben megmutatkozó presztízsviszonyok és normatív törekvések további vizsgálata nemcsak megkerülhetetlen, de reményeim szerint idővel még közelebb vihet annak a megértéséhez, hogy miként is használhatók fel tudományos szempontból a leginkább hatékonyan az oklevelek névanyagának ezek a rétegei. Legyen szó egy-egy adat értékeléséről, etimológiáról, nyelvi-etnikai rekonstrukcióról vagy bármilyen más névtörténeti vizsgálatról.

\subsubsection{Latinizálás és az oklevelek névhasználata mögötti vulgáris név- formák rekonstruálása}

Az okleveles szórványok nyelvészeti feldolgozásának már sokszor önmagában is korlátokat szab az adatok kiolvasásának a nehézsége, illetve az ebből fakadó bizonytalanság. Azonban nemcsak az oklevelek írása és helyesírása az, ami olykor a nyelvi valóság rekonstruálásának az útjában áll. A tulajdonnevek latinizálásának a gyakorlata a középkori oklevelekben ebböl a szempontból is külön figyelmet érdemel.

Mint már korábban volt róla szó, az oklevelek írói azokat a neveket, amiket lehetett és szokás volt, részben vagy egészében latinra fordítva fogalmazták bele az oklevelek szövegébe. Az azonban aligha feltételezhető, hogy ezek a latinizált névformák az élö, vulgáris nyelvhasználatnak is a részeivé váltak volna. Nyelvészeti szempontból az okozza a legfőbb problémát, hogy ezek el is fedik a korabeli valós nyelvhasználatot, s - ahogy HOFFMANN ISTVÁN fogalmaz - a latinizáló formákból csak nyelvészeti eszközökkel bonthatók ki a vulgáris névalakok (2007: 22). Ez azonban nem minden esetben problémamentes. Erre vonatkozóan említek a következőkben néhány szepesi példát említeni.

A szakirodalomban különösen nagy figyelmet kapnak a villa 'falu' vagy más latin földrajzi köznév és egy személynév alkotta szerkezetek, amelyek megítélése a szepesi névanyagban is okoz bizonytalanságot. Közismert, hogy ezek mögött nem tulajdonnévi értékben álló birtokos szerkezet, egyrészes és kétrészes földrajzi név egyaránt állhatott (vö. BÉNYEI 2012: 77-78, különösen pedig HOFFMANN 2004: 31-37, 2007: 43-52). Ez pedig egy név keletkezési idejének vagy az elsődleges nyelvi megformáltságának a szempontjából nem lényegtelen

${ }^{18}$ Ugyan nem szepesi példa, de nagyon tanulságos eset arra vonatkozóan, hogy mikor és miért kerülhettek mégis a latin nyelvü oklevelekbe német névformák akkor, amikor azoknak magyar nyelvű névpárja is ismeretes volt. Tamás esztergomi érsek egy 1317-es okleveléből kiderül ugyanis, hogy egy alkalommal egy birtok határpontjait tudatosan többnyire németül (in wlgari Teutonico) adták meg, mégpedig azért, hogy az adományt kapó osztrák szerzetesek könnyebben azonosíthassák azokat (ob favorem fratrum ..., quia in illis partibus plures sunt Teutonici et ut facilius veniant ad noticiam plurimorum) (vö. Dl. 56731, AOklt. 4: 209, MAREK 2015: 158, RegSlov. 2: 113-114). 
kérdés. Jellemzően még a birtoklástörténeti adatok fényében és a teljes megyei anyag kontextusában sem lehet teljes bizonyossággal megállapítani, hogy például az 1286-ban felbukkanó villa Abraham adat (Dl. 38876) körülírást, esetleg már a későbbi Ábrahámfalva (Abrahámovce) nevének a fordítását rejti-e, vagy pedig eredetileg a névnek létezett egy egyrészes Ábrahám formája is, s az idézett 1286os adat még erre a formára utal. Az ráadásul, hogy egy hely megnevezése elsődlegesen egy- vagy kétrészes névként keletkezett, nemcsak az adott név etimológiája és változása kapcsán fontos, hanem az egyes névtípusok kronológiája szempontjából is alapvető kérdés. Sok esetben ráadásul nem csupán a latinizált forma mögött rejtőző vulgáris névalak rekonstruálása problémás, hanem e szerkezetek tulajdonnévi státuszának a megítélése is kérdéses. Talán kijelenthető, hogy egy tamásfalvi (Spišské Tomášovce) rész eladása kapcsán keletkezett 1317-es határjárásban a későbbi Arnótfalvára (Arnutovce) utaló terre Magni Arnoldi et suorum sociorum (Dl. 71624, vö. RegSlov. 2: 99-100) nem a vulgáris nyelvhasználatban létező helynévi forma fordítása, hanem a birtokosokra utaló megfogalmazás, akárcsak a későbbi Závada (szl. Levoča-Závada) 1317-es első villa magister Gothfredii (Df. 281727) formában történő említése is. Továbbá jó eséllyel hasonló sejthető egy 1315-ös oklevél Erdőfalvára (Stará Lesná és Nová Lesná) vonatkozó super metis silvestris ville Menhardi (Dl. 1861, vö. RegSlov. 2: 44-45) leírása mögött is, ugyanis a települést 1294-ben már Erdeu falua formában is említik (Df. 280760). De az előzőkhöz képest talán már nagyobb eséllyel helynévi említésről van szó a mára elpusztult Marcelfalva 1305-ös ad villam Marsily adata (Dl. 63629) esetében, ugyanis az oklevél szövegében már nem az alapító Marcel, hanem a fia szerepel (Ricolpho filio Marsily), ami azt jelezheti, hogy ebben az esetben már egy kialakult helynévröl van szó. Más esetekben azonban - elsösorban egy-egy hely kialakulásának az idejére vonatkozóan — a kérdés jórészt nyitott marad.

A vulgáris névformák rekonstruálásakor többnyelvü területeken az is problémát jelenthet, hogy eleve melyik vulgáris nyelv adatát rekonstruáljuk a latinizált névforma alapján. Noha HoFFMANN, RÁCZ és TóTH a teljes Kárpát-medencére vonatkozóan megállapítja, hogy a latinizáló névhasználat mögött inkább magyar neveket sejthetünk, s csak ,igen ritkán szláv vagy német” helyneveket (vö. 2018: 76), a régi Szepes vármegye nyelvi-etnikai viszonyait figyelembe véve például Béla (Spišská Belá) település 1357-es superiori Bela (F. 9/2: 620-621) adata egyaránt utalhat a magyar Felsöbéla Felbéla, a szláv Horná Belá Vyšná Belá vagy esetleg a német Oberbela névre. ${ }^{19}$

${ }^{19}$ Ugyanakkor egyediségéből adódóan — ti. a település és birtok neve kapcsán efféle differenciálódásnak egyébként nincs nyoma — esetleg pusztán annyit is jelenthet, hogy 'a falu vagy birtok felső része'. 
Vizsgálataim jelenlegi szakaszában azt gondolom, hogy egyes esetekben elvi szinten, mintegy hipotézisként — mindenképpen érdemes számolni azzal a lehetőséggel, hogy a szepesi helyekre vonatkozó latinizált névformák valójában nem magyar, hanem szláv vagy német nevet rejtenek. A magyar szakirodalmi gyakorlat alapján talán szokatlannak tünhet, hogy például az egykor Csütörtökhelytől (Spišský Štvrtok) északnyugatra fekvő, mára elpusztult Komárfalva 1294-es villa Kamar (Dl. 14015) adata kapcsán — amennyiben az már helynévi értékkel bír - ne egy Komár Komárfalva, hanem inkább egy szláv Komarovce formát rekonstruáljunk. Ez utóbbi névalak esetében azonban azt mindenképpen számításba kell vennünk, hogy a településnek a középkorban nemcsak Komárfalva, hanem Komoróc adatai is feltünnek, sőt ez utóbbi válik később általánossá (vö. Dl. 26733, Df. 285526, illetve Dl. 13473, Dl. 74832, Dl. 74826, Dl. 84688, D1. 84689, D1. 68857). És ha mindezt annak a fényében vizsgáljuk, amit a Hotkóc névforma végződésével kapcsolatban az előzőekben tárgyaltam, akkor azt gondolom, hogy a kérdésfelvetés Szepes vármegye nyelvi-etnikai rekonstrukciója során megkerülhetetlen. MILOŠ MAREK — nem konkrétan e példa, hanem a névtípus kapcsán — továbbá még azt is feltételezi, hogy a szlávos névalakok kora középkori forrásokban tapasztalható hiányának s az e mögött álló okleveles gyakorlatnak a fényében egyébként nemcsak a Komoróc, hanem a Komárfalva típusú adatok mögött is szláv vulgáris névforma, azaz esetünkben a Komarovce húzódik meg (vö. 2015: 163-164).

Azt gondolom, a kérdés megítélése - mivel a középkori helynevek etnikai vonatkozásai tapasztalataim szerint érzékeny területnek számítanak a kutatók körében — különösen nagy körültekintést igényel. Egy-egy esetben csak a szükebb terület nyelvi-etnikai viszonyainak, valamint helytörténeti-birtoklástörténeti hátterének, illetve a kérdéses adatot tartalmazó oklevél névhasználatának, sőt eleve az oklevelet kiállító szerv gyakorlatának a fényében juthatunk biztosabb következtetésre. Mindezek ismerete híján, a kérdést leegyszerüsítve, pusztán statisztikai — netalán ideológiai — alapokon könnyen téves következtetésekre juthatunk, bármelyik formát is tesszük meg a rekonstrukció eredményének.

\subsection{Az oklevelek keletkezésének helye és a nyelvi hüség}

Végezetül egy talán kevésbé közismert vizsgálati szempontról szeretnék néhány szót ejteni. Úgy gondolom, hogy az oklevelek keletkezésének a helye is lehet olyan tényező, amely olykor érdemben befolyásolhatja az oklevelekben fennmaradt tulajdonnévi szórványok nyelvi megítélését.

A magyar szakirodalomban hagyományosan két álláspont különült el a tekintetben, hogy az oklevelek helynévi szórványai mennyire tükrözik pontosan a helyben használatos névformákat. BENKÖ LORÁND szerint az oklevélírók a lehetőségekhez mérten törekedtek a nyelvi hüségre, s ,igyekeztek visszaadni azt a 
kiejtést, amelyen a kérdéses neveket azon a vidéken nevezték, ahol előfordultak" (1957: 38). Ezzel szemben BÁRCZI GÉZA egy helyütt úgy fogalmaz, hogy kérdéses, „vajon a helynévnek az oklevélben szereplö hangalakja valóban ugyanazon vidék nyelvét tükrözi-e" (1951: 6). Legutóbb HOFFMANN ISTVÁN, RÁCZ ANITA és TÓTH VALÉRIA tértek vissza a kérdéshez, s igyekeztek a problémát a maga összetettségében kezelni, illetve kialakítani egy olyan megközelítést, amelyben az oklevélírók nyelvi lenyomata és az oklevelek szórványai mögött álló nyelvi valóság egyes rétegei elválaszthatók egymástól (vö. 2018: 46-47). Az általuk bemutatott szempontokon túl én azt gondolom, hogy egy oklevél szórványainak az értékelésekor azt is érdemes — $\mathrm{s}$ bizonyos kérdésekben szükséges — figyelembe venni, hogy az adott irat hol keletkezett, ugyanis ennek a nyomai véleményem szerint az oklevek névhasználatában is kimutathatók.

Ismeretes, hogy az okleveles gyakorlat elterjedésével párhuzamosan a magyar királyság területén idővel kialakultak olyan helyi intézmények, az ún. hiteleshelyek, amelyek az országos szervek munkáját segítendő oklevél-kiállítási jogot kaptak. Ezekre a leggyakrabban káptalanokhoz vagy konventekhez köthető intézményekre az volt a jellemző, hogy joghatóságuk csak egy-egy szükebb, egykét vármegyényi területre terjedt ki (vö. ECKHART 1914/2012: 67-68, KMTL. hiteleshely). Ennek következtében a hiteleshelyek írnokai - mint ahogy a szepesi káptalanéi is - a hozzájuk tartozó terület helyneveit a napi munkájukból, de részben talán még a helyismeretükből adódóan is többnyire jól ismerték. ${ }^{20}$ Ezzel szemben a királyi kancellária, a nádori vagy az országbírói hivatal a teljes királyságra vonatkozóan bonyolított ügyeket, s a Szepesség kapcsán ide sorolható még néhány olyan hiteleshely is, mint például a jászói konvent vagy az egri káptalan, amelyek területileg igen kiterjedt joghatósággal rendelkeztek, s a középkor során rendszeresen állítottak ki oklevelet szepesi ügyekben is.

Ennek nyelvészeti szempontból a tekintetben látom jelentőségét, hogy a kancellária vagy más országos hivatal, esetleg távolabbi hiteleshely írnokai jellemzően nem ismerték a helyi viszonyokat, nem jártak az ügyben szereplő helyeken, s ha az ügy kapcsán olykor mégis ki kellett szállniuk például egy-egy határjárás miatt, sem napi rutinjukból, sem helyismeretükből adódóan nem ismerték és nem használták az adott neveket, ráadásul az egész országra kiterjedő hivatali munkájukból adódóan egészen más névismerettel, s ebből adódóan feltehetően más

\footnotetext{
${ }^{20}$ ECKHART FERENC ennek a jelentőségét annak kapcsán emeli ki, hogy minden hiteleshelyi eljárás során szükséges volt az ügyben érintett felek személyazonosságának a tisztázása, s mivel egy-egy hiteleshelyhez mindig csak korlátozott területről fordultak ügyfelek, ez az azonosítás nem jelentett különösebb problémát (vö. 1914/2012: 112-113). Ha belegondolunk, egy Szepes nagyságú vármegye esetében a birtokok és birtokosok, illetve a jogi eljárást igénylö ügyek száma adott időszakban valóban átlátható nagyságú volt, így az illetékes hiteleshelyen dolgozó írnokok számára többségében nemigen lehettek idegenek azok a személy- és helynevek, amelyekkel a munka során rendre találkoztak.
} 
névkompetenciával rendelkeztek, mint az adott területen illetékes hiteleshelyeken dolgozó írnokok. ${ }^{21}$ Így olykor joggal merül fel a kérdés, hogy a nem helyben kiadott oklevelek névadataiból lehetséges-e egyáltalán az adott név helyben használt változatának hangtani-nyelvjárási sajátságait megállapítani. Annál is inkább, mert a szepesi ügyekben eljáró országos hivatalok a területi távolság miatt vélhetően döntően írásban benyújtott anyagok és korábbi oklevelek, esetleg megbízottak által közvetített információk alapján dolgozhattak, így a helynevek helyben kiejtett formája bizonyosan csak sokszoros szürőn keresztül jutott el hozzájuk. ${ }^{22}$

Ennek kapcsán mindenképpen hangsúlyozni kell azt is, hogy az oklevél kiadási helyének a figyelembevétele az adatok értelmezése során nem tesz automatikusan jobb forrássá egy helyben készült, illetve rosszabb forrássá egy máshol készült oklevelet. Ugyanis egy irat nyelvészeti megbízhatósága ezen kívül is számos egyéb tényezőtől függött, s így e szempont érvényesítése minden esetben más szempontokkal együtt vezethet olykor eredményre.

Az oklevél kiállítási helyének névhasználatra vonatkozó következményei természetesen a legtöbb esetben nem nyilvánvalóak, mivel nincs olyan egyértelmü viszonyítási pont, amelyhez képest a kérdést meg lehetne ítélni. Ugyanis amit egy régi név hangtani-alaktani felépítéséröl biztosan tudunk, azt jellemzően csak az oklevelekből tudjuk, s a korszakra vonatkozó nyelvtörténeti ismereteink is erősen bele vannak ágyazva az okleveles adatok olvasatának és nyelvi értékelésének a kontextusába. Ugyanakkor Szepes vármegyére vonatkozóan bizonyos mintázatok már kutatásaim mostani fázisában is kirajzolódni látszanak.

Ahogyan a Szepességre vonatkozó oklevelek esetében látszik, a helyi névanyagot nem vagy kevéssé ismerő hivatalok képviselői lényegesen gyakrabban hibáztak a nevek leírásakor, mint a szepesi káptalan írnokai, hiszen az országos hivatalok vagy távolabbi hiteleshelyek írnokai a rendelkezésükre álló írásbeli vagy szóbeli források adatainak az értelmezésekor nem támaszkodhattak a saját névismeretükre, vagy pedig éppen a névismeretük és a névkompetenciájuk tévesztette meg őket egy-egy számukra ismeretlen hang- vagy betüsor leírásakor

${ }^{21}$ Természetesen a középkori írnokok névkompetenciájának a vizsgálata — főleg általában megfogalmazva - lehetetlen feladat, az oklevelek névhasználata — a sok más változó miatt, ami azt az írnokok névkompetenciáján túl befolyásolta — nem vagy csak kis mértékben teszi lehetővé ennek a tisztázását. A leegyszerüsítés tudatában mégis alkalmazom ezt a fogalmat e helyütt, ugyanis azt azért fontosnak tartom kiemelni, hogy a különböző hivatalokban dolgozó írnokok a munkájukból adódóan alapvetően másféle módon viszonyulhattak a nevekhez, mint egy korabeli kisbirtokos vagy jobbágy.

${ }^{22}$ Ráadásul a helyben készült oklevelek kapcsán ugyanúgy feltehető, hogy azok nyelvészeti forrásértéke az előző fejezetekben ismertetett sajátságok miatt — úgymint normatörekvések és nyelvi presztízs - már eleve bizonytalanná teszik a szórványok nyelvi hüségének a pontos megítélését. Azt gondolom, hogy e tekintetben valóban egy sokváltozós rekonstrukciós módszer az, ami biztosabb, ám olykor kevésbé látványos eredményt hozhat egy-egy oklevél adatainak a feldolgozása során. 
vagy átírásakor. Annak a megítélése azonban, hogy mi számít hibának, nem mindig egyértelmü, ezért statisztikákat ezzel kapcsolatban egyelőre nem készítettem. Ráadásul a romlott alakok hátterében sok esetben valóban egyszerü tollhiba áll, aminek pedig a nyelvészeti vizsgálata jórészt irreleváns (vö. mindezekhez SZENTPÉTERY 1942, illetve KENYHERCZ 2016). Az alábbi példák ezért elsősorban azt szemléltetik, hogy a hibázás nem minden esetben egyszerü betükihagyás, betüfelcserélés vagy betüduplázás, hanem a hátterében olykor valóban egy-egy név ismeretének a hiánya állhatott.

Jó eséllyel ez utóbbi mutatkozik meg akkor, amikor Vitkfalva (Vítkovce) 1339-ben Mykofalua (Df. 264170) formában kerül elö egy esztergomi káptalan által készített iratban, $\mathrm{s}$ hasonló példa lehet Szécsi Miklós országbíró 1383-as oklevelében Jekelfalva (Jaklovce) Ilkefalua adata (Dl. 83399), valamint ide sorolhatónak tünik még a Meldur név (Podhorany) Zsigmond király 1426-os oklevelében Melkwr formában való felbukkanása is (Dl. 83629). Ugyancsak efféle hibának látszik az egri káptalan 1474-es oklevelében Németgörgő (Spissky Hrhov egykori része) 1369-re vonatkozó Nemesgargov adata (Dl. 63862), illetve II. Ulászló 1499-es oklevelében Batizfalva (Batizovce) 1407-es említésének a villa Bonsi formában történő átírása, ami vélhetően a villa Botisi forma félreolvasásából állhatott elö (Df. 266951). Nyilvánvaló félreértés Leszkovány (Lieskovany) 1351-es Kyskohan adata is, amelyet Miklós nádor írnoka írt le az esztergomi káptalan 1327-es oklevelének az átírása során (Dl. 2460). ${ }^{23}$

A fentieken kívül még számos példát lehetne hozni a nem egyszerü tollhibákra visszavezethető romlott alakokra, de talán már ennyi adat is mutatja azoknak a hibáknak a jellegzetességeit, amelyek hátterében talán a névismeret hiánya áll. Különösen tanulságosak azok az esetek, amikor ezeket a rontott alakokat tartalmazó okleveleket a szepesi káptalanban viszont helyes, azonosított és javított névformákkal írják át. Például a Betlenfalva (Betlanovce) részeként létező egykori Zsgyár birtok neve II. Lajos 1519-es oklevelében Schaar formában szerepel, ám ennek az oklevélnek a szepesi káptalan által ugyanebben az évben készített átiratában a hibás helyen már helyesen a Sgyar (Dl. 63890) forma szerepel. Ide kapcsolható I. Károly 1323-as oklevele is, amelyben Kistoporc (Toporec egykori része) neve hibásan Kyskupurch formában lett leírva (Dl. 63648), de amikor a szepesi káptalan 1327-ben átírta ezt az oklevelet, a káptalan írnoka ebben a

${ }^{23}$ Szempontunkból nem igazán lényeges kérdés, hogy a hibázást a nádor vagy az esztergomi káptalan írnoka követte-e el, hiszen egyik sem helyi hivatal, ugyanakkor a filológiai pontosság érdekében megemlíthető, hogy az esztergomi káptalan 1327-es oklevelének — noha az eredeti példánya nem maradt fenn - ezen az 1351-es átiraton kívül fennmaradtak egyéb átiratai is, amelyek alapján valószínüsíthető, hogy az 1351-es oklevél a hiba forrása. Az egyéb átiratokban a kérdéses hely a következőképpen olvasható: Dl. 74868/1 (Zsigmond király): Lyskoan, Dl. 74868/2 (Zsigmond király): Nyskuan, Dl. 74876 (Garai Miklós nádor): Leskowan. 
szövegrészben nem a hibás alakot másolta át, hanem az ügy és a név ismeretében kijavította azt a helyes Kystuporch formára (Dl. 63655).

Természetesen előfordulnak hibák a szepesi káptalanban készült iratokban is, de ezek szinte mindig egyszerü tollhibának tünnek, s esetükben jellemzően nem merül fel a fentiekhez hasonló tévesztés gyanúja. ${ }^{24}$

Az imént bemutatott hibák egyébként — még ha a hátterükben esetleg más nevek analógiás hatása is állhatott - nyilvánvaló tévesztések, azaz nyelvészeti szempontból nem is számítanak igazán érdekesnek. A kutatásaim során azonban sokkal több tanulsággal jár azoknak az eseteknek a feltárása, amelyek az oklevél kiadási helyének a figyelembevételével más, nyelvi szempontból is releváns különbséget mutatnak a helyben és a nem helyben készült oklevelek névhasználata szempontjából. Igaz, ezeknek az eseteknek a megítélésekor jellemzően nincs biztos fogódzónk azon kívül, hogy egyes helyek neve hangtani-alaktani variánsokban adatolható.

Ennek illusztrálására példaként a szepesi Garancs (Granč-Petrovce) település 15. századi adatait hozhatjuk fel. A hely neve ebben az időszakban Grancs és Garancs formában egyaránt adatolható, a két névalak hangtani különbsége a nevet a szókezdő mássalhangzó-torlódásokat érintő tipikus ómagyar kori nyelvi változáshoz kapcsolja (vö. KENYHERCZ 2013b). Noha a Grancs Garancs névpár tagjai közti különbség egyaránt utalhatott magyar-szláv, illetve magyar nyelven belüli variánsok használatára, az oklevelek keletkezési helyének a szempontjából most mégis inkább arra szeretnék rámutatni, hogy az egyes változatok használatát - függetlenül attól, hogy a régi magyarban használatos volt-e mindkét forma bizonyos esetekben talán az oklevél kiadásának a helye is befolyásolhatta.

Az alábbiakban a település nevének azok a 15. századi adatai láthatók, amelyek vagy valamelyik országos hatóság, vagy a szepesi káptalan által kiállított oklevelekben maradtak fenn:

1407/1407: Granch (Dl. 60532) 1407: Granch (Dl. 60532); 1413: Granch (Dl. 60570); 1415/1415: Granch (Dl. 63742); 1415: Granch (Dl. 60591);

${ }^{24}$ Efféle figyelmetlenségből adódó hibára hozható példaként a szepesi káptalan 1374-es oklevele, ahol Zsaluzsán (egykori birtok a mai Ordzovany közelében) neve tizenkét alkalommal Jalusan, egy alkalommal viszont Jalisan formában szerepel (Dl. 74834). Vagy ide sorolható Csantafalva (Jánovce-Čenčice) 1371-es Chonafalua adata, különösen annak a fényében, hogy az oklevélben egy korábbi szöveghelyen Chontafalua áll (Dl. 75019). Nyelvészeti szempontból talán ugyanígy figyelmen kívül hagyható Milaj (egykori település a mai Spišský Hrušov mellett) 1368-as Malay adata is, hiszen az oklevélben pár sorral lejjebb a név már helyesen Mylai formában szerepel (D1. 39679). Az mindenesetre, hogy a szepesi káptalan oklevelei a vizsgált időszakban a nevek szempontjából összességében meglehetősen pontosnak mondhatók, részben annak is tulajdonítható, hogy a szepesi káptalan a középkor idején azok közé a hiteleshelyek közé tartozott, ahol az oklevelek kiállítása többnyire nagyobb gonddal történt meg (vö. SZENTPÉTERY 1942: 419-420). Ennek a fényében más hiteleshelyek oklevélkiadói tevékenységének az ismerete eredményezhetne nagyobb rálátást a problémára. 
1416/1416: Granch (Dl. 10417) 1416: Granch (Dl. 10417); 1416/1416: Granch (Dl. 83584); 1418/1418: Granch (Dl. 60613); 1419: Granch (Df. 263824); 1422/1422: Garanch (Dl. 60639) 1422: Garanch (Dl. 60639); 1422/1423/ Más.: Grancs (Df. 286328); 1423: Garanch (Dl. 83615) 1423: Grancz (Dl. 83615); 1423/1423: Granch (Dl. 83613); 1424: Granch (Dl. 39638); 1424: Granch (Dl. 60655) 1424: Granch (Dl. 60655); 1442: Granch (Dl. 39739/Dl. 60762); 1444: Granch (Dl. 39746); 1471: Grancz (Dl. 60822); 1479: Garanch (Df. 263863) 1479/1479: Granch (Dl. 63866).

Ha pusztán az adatokat nézzük, akkor azt mondhatjuk, hogy a 15. században a név formája fonológiai szempontból szinkrón varianciát, ingadozást mutatott, ami egyébként egyáltalán nem szokatlan jelenség a hangtörténeti változások esetében. Ha azonban ehhez az adatsorhoz a források kiadási helyét is hozzákapcsoljuk, azt láthatjuk, hogy a hangszerkezeti szempontból ekkor talán magyarosabb hangzásúnak tekinthető Garancs forma — közvetlenül vagy közvetetten — mindig valamilyen módon a királyi kancellária vagy más országos méltóság által kiadott oklevélhez kapcsolódik, míg a szepesi káptalan által kiadott oklevelekben a név eredeti hangszerkezetét tükrözö Grancs forma volt a használatos. ${ }^{25}$

Különösen is árulkodó egy Zsigmond király által kiadott, eredetiben fennmaradt 1423-as oklevél (Dl. 83615), amelyben a név Garanch formában fordul elö, viszont az oklevél hátlapján található egy üggyel kapcsolatos korabeli feljegyzés a szepesi káptalan írnokától, amelyben a település neve már Grancz alakban szerepel. Hasonló kettősség figyelhető meg Bátori István országbíró eredetiben fennmaradt 1479-es parancsa és annak átirata esetében is: a település neve az eredeti parancsban Garanch formában adatolható (Df. 263863), a szepesi káptalan azonos évben készített szó szerinti átiratában viszont már Granch formában szerepel a név (Dl. 63866).

A kisszámú adat miatt nyilvánvalóan nagyon körültekintően kell az efféle megfigyelésekből adódó következtetésekkel bánni, ugyanakkor a hiteleshelyek írnokainak a névismeretével kapcsolatban elmondottak alapján elméletileg nem tartom kizárhatónak, hogy ebben az esetben a királyi kancellária és az országbíró írnokai a nyelvi presztízs, a normatörekvések, esetleg saját nyelvi kompetenciájuk alapján valóban más formában használták a nevet, mint ahogy az a helyi nyelvhasználatban előfordult. S ezek alapján azt sem tartom kizártnak, hogy azokban a mandátumokban, amelyek ma már csak a szepesi káptalan átiratában

${ }^{25}$ Egészen pontosan arról van szó, hogy a szepesi káptalanban készült eredeti vagy a káptalan által átírt oklevelekben egy oklevéltől eltekintve mindig Granch vagy Grancz formában kerül elő a név (vö. Dl. 60532, Dl. 60570, Dl. 63742, Dl. 60591, D1. 10417, Dl. 83584, D1. 60613, Df. 263824, Dl. 83613, Dl. 39638, Dl. 60655), míg az országos hatóságok által készített iratokban egy kivételtől eltekintve Garanch adatok szerepelnek (Dl. 60639, D1. 83615). Az eset részletes elemzéséhez lásd KENYHERCZ 2016: 37-41. 
olvashatók (Dl. 60532, Dl. 63742, Dl. 10417, Dl. 83584, Dl. 60613, Dl. 83613), eredetileg néhány további esetben is a Garancs forma szerepelt, csak a káptalan írnoka az átírás során azt Grancs formára változtatta át.

Ha messzemenő és általánosítható következtetéseket nem is lehet ennek a névpárnak a példájából levonni, annyi mindenesetre megállapíthatónak tünik, hogy a szinkrón ingadozás helyett az oklevelek keletkezési helyének a figyelembevétele alapján Szepesben inkább a Grancs lehetett a használatosabb forma, esetleg még a magyar nyelvü beszélők körében is, mert a szepesi írnokok következetesen ezt a formát használták a dokumentumaikban. ${ }^{26} \mathrm{E}$ tekintetben nem lényegtelen körülmény, hogy a szepesi káptalan írnokai közelebbröl is ismerhették a név helyben használatos formáját, annál is inkább, mivel Grancs öt kilométerre van a káptalan épületétöl, de a munkájukból adódóan is mindenképpen gyakran találkoztak e névvel.

A helyben használt oklevelek e feltételezett sajátságát mindenesetre nagyon nehéz megítélni, ugyanis a fentebb tárgyalt normatörekvések és a nyelvi presztízs tudatos vagy tudattalan hatása a szepesi káptalanban vagy más hiteleshelyen is eredményezhette azt, hogy az oklevélbe a név végül — az írnok névismeretétöl függetlenül — nem a helyi névhasználók által használatos hangtani-alaktani sajátságokat tükröző változatban került bele, hanem a tulajdonképpen standardizált, hivatalos alakjában, amit például a királyi kancelláriával való közös munka is jelentős mértékben befolyásolhatott.

Végül visszatérve BENKÖ LORÁND megállapításához, miszerint az oklevelek leírói ,igyekeztek visszaadni azt a kiejtést, amelyen a kérdéses neveket azon a vidéken nevezték, ahol előfordultak" (1957: 38), azt gondolom, azt mindenképpen hozzá kell ehhez tenni, hogy ennek a tükröztetésére csak abban az esetben volt lehetőség, ha az írnoknak egyáltalán voltak efféle ismeretei. Ugyanakkor mivel már a helyi írnokok adatközlését is számos tényezö befolyásolta, csak azért, mert nem helyben készült egy oklevél, hiba lenne azt nyelvi értelemben kevésbé hü forrásnak tekinteni. Viszont egyedi esetekben az oklevél kiadási helyének a figyelembevétele meglátásom szerint mindenképpen termékeny vizsgálati szempont lehet.

\section{4. Összegzés}

A középkori oklevelek szórványain alapuló kutatások esetében a tudományos megismerés fejlődése - a Kárpát-medencére vonatkozó helynévi adatállományok mind teljesebbé tétele mellett — az okleveles források egyre alaposabb megértésének a függvénye. Az oklevelezési gyakorlat közvetlen vagy közvetett

${ }^{26}$ Egyetlen esetben nem, amikor nemcsak a mandátum szövegében, hanem a káptalan saját szövegezésü részében is a Garanch szerepel (Dl. 60639). Ám ez esetleg mégis magyarázható azzal, hogy az írnok ragaszkodott a királyi parancs névhasználatához. 
nyelvi vonatkozásainak egyre mélyebb feltárása ugyanis reményeim szerint nyilvánvalóbbá teheti az oklevelek valódi nyelvészeti forrásértékét, minden lehetöségével és korlátjával együtt, $\mathrm{s}$ elvezethet a bennük szereplö vulgáris nyelvi adatoknak a tudományos tekintetben még reálisabb értelmezéséhez.

\section{Irodalom}

AOklt. = KRISTÓ GYULA szerk., Anjou-kori oklevéltár. Documenta Res Hungaricas tempore regum Andegavensium illustranta. Budapest-Szeged, Csongrád Megyei Levéltár, Szegedi Középkorász Mühely, 1990-.

BÁBA BARBARA 2016. Földrajzi köznevek térben és időben. A Magyar Névarchívum Kiadványai 39. Debrecen, Debreceni Egyetemi Kiadó.

BÁRCZI GÉZA 1951. A tihanyi apátság alapitólevele mint nyelvi emlék. Nyelvészeti Tanulmányok 1. Budapest, Akadémiai Kiadó.

BÁRCZI GÉZA 1958. A magyar szókincs eredete. Második, bővített kiadás. Budapest, Tankönyvkiadó.

BENKŐ LORÁND 1957. Magyar nyelvjárástörténet. Budapest, Tankönyvkiadó.

BÉNYEI ÁGNES 2012. Helynévképzés a magyarban. A Magyar Névarchívum Kiadványai 26. Debrecen, Debreceni Egyetemi Kiadó.

BUJÁK GÁBOR 2015. A szepesi és pozsonyi prépostságok korai története a szlovák histográfiában. Forráskutatás és Történeti Segédtudományok 22: 3-51.

CDES. = MARSINA, RICHARD szerk. 1971-1987. Codex diplomaticus et epistolaris Slovaciae 1-2. Bratislava, Slovenská Akadémia Vied.

Cs. = CsÁNKI Dezsö, Magyarország történelmi földrajza a Hunyadiak korában 1-3., 5. Budapest, 1890-1913.

Df. = Diplomatikai Fényképgyüjtemény. Magyar Országos Levéltár, Mohács előtti gyüjtemény.

Dl. = Diplomatikai Levéltár . Magyar Országos Levéltár, Mohács előtti gyüjtemény.

E 158 = Magyar Országos Levéltár. Magyar kincstári levéltárak. Magyar Kamara Archivuma. Conscriptiones portarum 35. 1538-1696. MOL Filmtár 1645-1646. tekercs. 36. 1567-1620. MOL Filmtár 1646-1647. tekercs.

ECKHART FERENC 1914/2012. Hiteleshelyek a középkori Magyarországon. Die glaubwürdigen Orte Ungarns im Mittelalter. Budapest, Magyar Országos Közjegyzöi Kamara.

ENGEL PÁL 1987/2007. Töprengések az Árpád-kori sáncvárak problematikájáról. Müemlékvédelem 31: 9-14. Castrum 6: 11-18.

F. = FEJÉR GYÖRGY, Codex diplomaticus Hungariae ecclesiaticus ac civilis 1-11. Buda, 1829-1844.

FEJÉRPATAKY LÁSZLÓ 1918. Hiteleshely mint névmagyarázó. Magyar Nyelv 14: 169-173.

FeKete NAGY ANTAL 1930. A Petróczy levéltár középkori oklevelei 1. Levéltári Közlemények 8: 190-264. 
FEKETE NAGY AnTAL 1931. A Petróczy levéltár középkori oklevelei 2. Levéltári Közlemények 9: 38-111.

FeKete Nagy AnTal 1934. A Szepesség területi és társadalmi kialakulása. Budapest.

Gy. = GYÖRFFY GYÖRGY, Az Árpád-kori Magyarország történeti földrajza 1-4. Budapest, Akadémiai Kiadó, 1963-1998.

HA. = HOFFMANN ISTVÁN-RÁCZ ANITA-TÓTH VALÉRIA, Helynévtörténeti adatok a korai ómagyar korból 1. Abaúj-Csongrád vármegye. Debrecen, 1997. 2. Doboka-Györ vármegye. Debrecen, 1999. 3. Heves-Küküllö vármegye. 2012. 4. Liptó-Pilis vármegye. 2017. Debrecen, Debreceni Egyetemi Kiadó.

HoFFMANN IstVÁN 1997. Kiss Lajos: Földrajzi neveink nyelvi fejlődése. Magyar Nyelv 93: 87-95.

HoFFMANN IsTVÁN 2004. Az oklevelek helynévi szórványainak nyelvi hátteréröl. Helynévtörténeti Tanulmányok 1: 9-61.

HoFFMANN ISTVÁN 2007. A Tihanyi alapitólevél mint helynévtörténeti forrás. A régi magyar helynevek vizsgálatának alapkérdései. Akadémiai doktori értekezés. Kézirat. Debrecen.

HofFMANN ISTVÁN 2010. A Tihanyi alapitólevél mint helynévtörténeti forrás. A Magyar Névarchívum Kiadványai 16. Debrecen, Debreceni Egyetemi Kiadó.

HOFFMANN ISTVÁN-RÁCZ ANITA-TÓTH VALÉRIA 2018. Régi magyar helynévadás: a korai ómagyar kor helynevei mint a magyar nyelvtörténet forrásai. Budapest, Gondolat Kiadó.

Homza, MARTin 2009: Dzieje wczesnośredniowiecznego Spisza. In: HoMZA, MARTINSROKA, StAnISŁAW ANDRZEJ szerk., Historia Scepusii 1. Dejiny Spiša 1. BratislavaKraków, Slovensko-pol'ská komisia humanitných vied Ministerstva školstva SR a Ministerstva vedy a vyššieho školstva Pol'skej republiky-Katedra slovenských dejín UK Filozofickej fakulty Bratislava-Instytut Historii Uniwersytetu Jagiellońskiego Kraków. 126-327.

KARÁCSONYI JÁNOS 1901. Halavány vonások hazánk Szent István korabeli határairól. Századok 35: 1039-1058.

KARÁCSONYI JÁNOS 1902. A hamis, hibáskeltü és keltezetlen oklevelek jegyzéke 1400-ig. Budapest, Magyar Tudományos Akadémia.

KENYHERCZ RÓBERT 2013a. A középkori oklevelek hangtörténeti forrásértékének értékéhez. Magyar Nyelvjárások 51: 59-72.

KENYHERCZ RÓBERT 2013b. A szókezdö mássalhangzó-torlódások az ómagyar korban. A helynevek hangtörténeti forrásértéke. A Magyar Névarchívum Kiadványai 28. Debrecen, Debreceni Egyetemi Kiadó.

KENYHERCZ RÓBERT 2014. Helynévi adatok Szepes vármegye dikális összeírásaiból. Magyar Nyelvjárások 52: 229-248.

KENYHERCZ RÓBERT 2015. A Urbaria et conscriptiones címü gyüjtemény Szepes vármegyére vonatkozó településnévi adatai. Magyar Nyelvjárások 53: 188-210.

KENYHERCZ RÓBERT 2016. A középkori oklevelek átírási gyakorlatának nyelvi vonatkozásai. Helynévtörténeti Tanulmányok 12: 7-44. 
KENYHERCZ RÓBERT 2018. On the names of the historical Szepes County. Folia Uralica Debreceniensia 25: 109-132.

KMHsz. = HoFFMANN ISTVÁN szerk., Korai magyar helynévszótár 1000-1350. 1. AbaújCsongrád vármegye. A Magyar Névarchívum Kiadványai 10. Debrecen, Debreceni Egyetem Magyar Nyelvtudományi Tanszéke, 2005.

KMTL. = Kristó Gyula szerk. Korai magyar történeti lexikon (9-14. század). Budapest, Akadémiai Kiadó, 1994.

KovÁCs Éva 2015. A Tihanyi összeirrás mint helynévtörténeti forrás. A Magyar Névarchívum Kiadványai 34. Debrecen, Debreceni Egyetemi Kiadó.

KovÁCs Éva 2018. A Százdi alapitólevél mint helynévtörténeti forrás. A Magyar Névarchívum Kiadványai 48. Debrecen, Debreceni Egyetemi Kiadó.

KovÁCs Helga 2019. Várnevek a középkori Magyarországon. Doktori értekezés. Kézirat. Debrecen.

KRISTÓ GYULA 1988. A vármegyék kialakulása Magyarországon. Budapest, Magvető Kiadó.

KRISTÓ GYULA 2000. Magyarország népei Szent István korában. Századok 134: 3-44.

KSA. = Kodeks Stanisława Augusta. Cronica magna Lechitarum et Polonorum. [Ca. 1401-1450.]

LABANC, PETER 2013. Vývoj šlachty na spiši do začiatku 14. staročia. Bibliotheca historica Tyrnaviensis 6. Trnava-Krakow, Spolok Slovákov v Pol’sku-Towarzystwo Słowaków w Polsce.

LABANC, PETER-GLEJTEK, MIROSLAV 2015: Spišské prepoštstvo na prelome stredoveku a novoveku 1. Príspevok k náboženským dejinám Spiša. Trnava-Krakow, Filozofická fakulta Trnavskej univerzity v Trnave-Towarzystwo Slowaków w Polsce.

LABANC, PETER 2020. K okolnostiam vzniku sídel na Zamagurí a vývoj ich držby do polovice 14. storočia. Almanach Stowacy w Polsce 21: 11-42.

Lipszky = LIPSZKY JÁNOS 1808. Repertorium locorum objectorumque in XII tabulis mappae regnorum Hungariae, Slavoniae, Croatiae et Confiniorum Militarium, Magni item Principatus Transylvaniae occurrentium. Buda.

MalovcovÁ, BožEnA szerk. 2008. Spišská Stará ves. Prešov, Universum.

MAREK, MILOŠ 2015. Slovenské miestne názvy v kontexte kancelárskej praxe stredovekého Uhorska. In: DomenovÁ, MARCELA-MAGDOŠKO, DRAHOSLAV szerk., Poznávanie dejín Slovenska. Pramene, metódy a poznatky. Prešov-Košice, Universum.

Monasterium = https://www.icar-us.eu/cooperation/online-portals/monasterium-net

N 78 = Magyar Országos Levéltár. Regnicolaris levéltár. Archivum regni. Országos öszszeírások. Ladula BB-CC. Ladula GG-HH 1715. évi összeírás. 7. téka.

NYIRKOS ISTVÁN 1997. A szóeleji mássalhangzó-torlódások feloldásának módjairól. Folia Uralica Debreceniensis 4: 113-156.

RÁCZ ANITA 2016. Etnonimák a régi magyar településnevekben. A Magyar Névarchívum Kiadványai 37. Debrecen, Debreceni Egyetemi Kiadó. 
RegArp. = SZENTPÉTERY IMRE 1923. Az Árpád-házi királyok okleveleinek kritikai jegyzéke. Regesta regum stirpis Arpadianae critico diplomatica 1/1. Budapest, Magyar Tudományos Akadémia.

RegDuc. = SZENTPÉTERY IMRE-ZSOLDOS ATTILA, Az Árpád-házi hercegek, hercegnők és a királynék okleveleinek kritikai jegyzéke. Budapest, 2008.

RegSlov. = VINCENT SEDLÁK, Regesta diplomatica nec non epistolaria Slovaciae 1-2. Bratislava, 1980-1987.

SCHMAUK = MICHAEL SCHMAUK, Supplementum analectorum terrae Scepusiensis 2. Szepesváralja, 1889.

SLÍZ MARIANN 2017. Személynévtörténeti vizsgálatok a középkori Magyarországról. Budapest, Magyar Nyelvtudományi Társaság. https://doi.org/10.26546/5061134.

SZENTGYÖRGYI RUDOLF 2010. Helynevek beillesztése korai latin nyelvü okleveleink szövegébe. Helynévtörténeti Tanulmányok 5: 33-45.

SZENTGYÖRGYI RUDOLF 2014. A tihanyi apátság alapitólevele 1. Az alapítólevél szövege, diplomatikai és nyelvi leírása. Budapest, ELTE Eötvös Kiadó.

SZENTPÉTERY IMRE 1930/1995. Magyar oklevéltan. Budapest, Magyar Történelmi Társulat. Reprint kiadás: Budapest, Hatágú Síp Alapítvány.

SZENTPÉTERY IMRE 1942. A középkori oklevélátiratok hibáinak elemzése. In: Emlékkönyv Melich János 70. születésnapjára. Budapest, Magyar Nyelvtudományi Társaság. 401-423.

SzŐCS TIBOR 2010. Egy második ,tatárjárás”? Belvedere Meridionale 3-4: 16-49.

SzÖKE MELINDA 2008. Régi helyneveink latinizálása. In: BÖLCSKEI ANDREA-N. CSÁSZI ILDIKÓ szerk., Név és valóság. A VI. Magyar Névtudományi Konferencia elöadásai. A Károli Gáspár Református Egyetem Magyar Nyelvtudományi Tanszékének kiadványai 1. Budapest. 267-271.

SzÖKE MELINDA 2013. A latin szöveg és helynévi szórvány kapcsolata különös tekintettel a garamszentbenedeki apátság alapítólevelének latinizáló helyneveire. Helynévtörténeti Tanulmányok 9: 57-76.

SzÖKE MELINDA 2015. A garamszentbenedeki apátság alapitólevelének nyelvtörténeti vizsgálata. A Magyar Névarchívum Kiadványai 33. Debrecen, Debreceni Egyetemi Kiadó.

TÓTH VALÉRIA 2016. Személynévadás és személynévhasználat az ómagyar korban. A Magyar Névarchívum Kiadványai 38. Debrecen, Debreceni Egyetemi Kiadó.

TÓTH VALÉRIA 2017. Személynévi helynévadás az ómagyar korban. A Magyar Névarchívum kiadványai 41. Debrecen, Debreceni Egyetemi Kiadó.

TÓTH VALÉRIA 2019. Módszertani problémák a Kárpát-medence régi helyneveinek etimológiai kutatásában. Helynévtörténeti Tanulmányok 15: 21-48. https://doi.org/10. 35528/Helynevtort/15/02.

$\mathrm{UC}=$ Urbaria et conscriptiones. Budapest, Magyar Országos Levéltár. Magyar kincstári levéltárak. Magyar Kamara Archívuma.

Zsoldos AtTiLA 2001. Szepes megye kialakulása. Történelmi Szemle 43: 19-31. 


\section{Philological Findings from the Historical Linguistic Study of Medieval Charters from Szepes County}

My paper introduces the philological findings derived from the linguistic analysis of medieval charters for Szepes County. During the discussion of various factors, my ultimate objective is to find out how the proper name data of the charters may be used for the purposes of research in historical linguistics and onomastics. Although the observations and hypotheses are based on the study of sources from Szepes specifically, I believe that the issues addressed in my paper also carry broader relevance and thus may be used both when interpreting remnants of charters and in the process of historical linguistic research based on these.

Keywords: Szepes County, medieval charters, linguistic prestige, Latinization

Kenyhercz Róbert

ORCID: https://orcid.org/0000-0001-6312-3532

Debreceni Református Hittudományi Egyetem

Kölcsey Ferenc Tanítóképzési Intézet

kenyhercz.robert@drhe.hu 